\title{
Technical challenges when scaling up macroinvertebrate DNA metabarcoding
}

\author{
Vasco Elbrecht, Dominik Buchner§, Markus Majaneval, Adriana Mordenteף, Jukka Aroviita\#, Torbjørn \\ Ekrem, Annette Baattrup-Pedersen", Jón S. Ólafsson", Richard K. Johnson^, Ann Kristin Schartau”, \\ Nikolai Friberg', Florian Leese§,§, Meissner Kristian?
}

‡ ETH, Zürich, Switzerland

$\S$ University of Duisburg-Essen, Essen, Germany

| Norwegian University of Science and Technology, Trondheim, Norway

II ZFMK, Bonn, Germany

\# SYKE, Oulu, Finland

a NTNU University Museum, Trondheim, Norway

« Aarhus University, Aarhus, Denmark

»Marine and Freshwater Research Institute, Reykjavík, Iceland

^Swedish University of Agricultural Sciences, Uppsala, Sweden

$\checkmark$ Norwegian Institute for Nature Research, Oslo, Norway

; Norwegian Institute for Water Research, Oslo, Norway

? SYKE, Jyväskylä, Finland

Corresponding author: Vasco Elbrecht (luckylion07@googlemail.com)

Received: 21 Feb 2021| Published: 04 Mar 2021

Citation: Elbrecht V, Buchner D, Majaneva M, Mordente A, Aroviita J, Ekrem T, Baattrup-Pedersen A, Ólafsson JS, Johnson RK, Schartau AK, Friberg N, Leese F, Kristian M (2021) Technical challenges when scaling up macroinvertebrate DNA metabarcoding. ARPHA Conference Abstracts 4: e64756.

https://doi.org/10.3897/aca.4.e64756

\begin{abstract}
Bulk macroinvertebrate DNA metabarcoding is proven a useful tool for routine assessment of freshwater ecosystems. Following a small scale study in 2017, using 18 samples from Finland Elbrecht et al. 2017, sampling and metabarcoding efforts were extended to a total of 297 official monitoring samples from Denmark, Sweden, Norway, Iceland, and Finland as part of the SCANDNAnet project. Macroinvertebrates from these samples were morphologically identified and subsequently DNA metabarcoding was performed. While the project was ultimately successful, documenting generally congruence between identification methods, we encountered a wide range of unexpected challenges when scaling sample throughput Meissner et al. 2020.
\end{abstract}


In this technical talk we highlight major roadblocks and potential solutions to improve turnaround time and reliability of future large scale DNA based monitoring efforts. We identify a need for tighter quality control and quality assurance in laboratory procedures, and exemplify the benefits of laboratory automation when processing hundreds of samples within a single week. We further discuss the need for scalable computational infrastructure, reliable sequencing providers and well-curated, purpose driven, macroinvertebrate reference databases for the Fennoscandian region. The lessons learned from the SCANDNAnet project will be indispensable in building a reliable infrastructure for a future DNA based monitoring of macroinvertebrates across Fennioscandia and beyond.

\section{Keywords}

DNA metabarcoding, WFD, water quality, macroinvertebrates

\section{Presenting author}

Vasco Elbrecht

\section{Presented at}

1st DNAQUA International Conference (March 9-11, 2021)

\section{References}

- $\quad$ Elbrecht V, Vamos EE, Meissner K, Aroviita J, Leese F (2017) Assessing strengths and weaknesses of DNA metabarcoding based macroinvertebrate identification for routine stream monitoring. MEE https://doi.org/10.1111/2041-210X.12789

- Meissner K, Aroviita J, Baattrup-Pedersen A, Buchner D, Ekrem T, Friberg N, Johnson R, Leese F, Majaneva M, Ólafsson J, Schartau AK, Elbrecht V (2020) Metabarcoding for use in Nordic routine aquatic biomonitoring - a validation study. TemaNord [ISBN 9789289368063] https://doi.org/10.6027/temanord2020-538 